Państwo-Prawo-Administracja

$2(1) / 2016$

ISSN 2451-1676

DOI: http://dx.doi.org/10.21784/PPA.2016.009

NINA DĄBROWSKA,

ROBERT KWAŚNIEWSKI

Uniwersytet Mikołaja Kopernika w Toruniu

\title{
Zasady nabywania prawa do „nagród jubileuszowych” przez pracowników samorządowych i ich oskładkowanie
}

The principles of acquiring the right to "jubilee awards" by local government employees and the calculation of their tax contributions

\section{Streszczenie:}

Przedmiotem niniejszej publikacji jest określenie zasad nabywania prawa do „nagród jubileuszowych” przez pracowników samorządowych będących specyficzną grupą zawodową, których uprawnienie w tym zakresie reguluje akt prawny zaliczany do pragmatyk zawodowych. Celem opracowania jest ustalenie, na podstawie analizy obowiązujących przepisów oraz orzecznictwa sądowego, zasad nabywania prawa do „nagród jubileuszowych” przez tę 
grupę zawodową oraz przeanalizowanie kwestii naliczania składek od „nagród jubileuszowych”, czyli odpowiedź na pytanie, kiedy przychód z tego tytułu wliczany jest do postawy wymiaru składek na ubezpieczenie społeczne, a kiedy wliczany być nie powinien.

Abstract: The goal object of this paper is to define the rules for acquiring the right to "jubilee awards" by local government employees who are a unique professional group whose entitlement in this respect is regulated by a relevant law related to public administration. The aim of the study is to determine (based on the analysis of existing legislation and case law) the principles of acquiring such right to "jubilee awards" and to analyze the question of calculating the contributions from "jubilee awards". In other words, the answer is sought for the question when the revenue from these awards should be included in the basis of social security contributions.

Słowa kluczowe: „nagrody jubileuszowe”; pracownicy samorządowi; oskładkowanie „nagród jubileuszowych”; zasady nabywania „nagród jubileuszowych".

Keywords: "jubilee awards"; local self-government employees; calculation of the contributions from "jubilee awards"; rules governing the acquisition of "jubilee awards".

\section{Wprowadzenie}

Ustawa o pracownikach samorządowych uchwalona 21 listopada 2008 r. ${ }^{1}$ jest aktem prawnym obejmującym w sposób kompleksowy kwestię pragmatyki zawodowej pracowników samorządowych. Stanowi odrębną regulację pracowniczą, obok ustawy z dnia 26 czerwca 1974 r. - Kodeks pracy², ze względu na specyficzną grupę zatrudnienia i szczególne jej uprawnienia. Uchwalenie nowej ustawy wiązało się z koniecznością dostosowania służby cywilnej do standardów obowiązujących w innych państwach europejskich (rekomendacja

Tekst jedn. Dz.U. z 2014 r., poz. 1202.

Tekst jedn. Dz.U. 2014 r., poz. 1502 ze zm. 
Komitetu Rady Europy nr R/2000/6 z 24 lutego 2000 r.). Ustawa o pracownikach samorządowych nie zawiera definicji legalnej „pracownika samorządowego", jedynie w art. 2, ustawodawca wskazuje te podmioty poprzez przedstawienie katalogu pracowników ${ }^{3}$. Zgodnie z tą regulacją „przepisy ustawy stosuje się do pracowników samorządowych zatrudnionych w:

1. urzędach marszałkowskich oraz wojewódzkich samorządowych jednostkach organizacyjnych,

2. starostwach powiatowych oraz powiatowych jednostkach organizacyjnych,

3. urzędach gmin, jednostkach pomocniczych gmin, gminnych jednostkach budżetowych i samorządowych zakładach budżetowych,

4. biurach (ich odpowiednikach) związków jednostek samorządu terytorialnego oraz samorządowych zakładów budżetowych utworzonych przez te związki,

5. biurach (ich odpowiednikach) jednostek administracyjnych jednostek samorządu terytorialnego".

W nawiązaniu do art. 166 ust. 1 Konstytucji Rzeczypospolitej Polskiej z dnia 2 kwietnia 1997 r. ${ }^{4}$ „wykonywanie zadań publicznych przez samorząd terytorialny służy zaspokajaniu potrzeb wspólnoty samorządowej”. Obejmuje to szerokie spektrum spraw z zakresu administracji publicznej, a także szeroko pojęte działania uchwałodawcze, gospodarcze i finansowe. Do zadań publicznych zalicza się zadania własne oraz zadania zlecone $\mathrm{z}$ zakresu administracji rządowej. Należy zauważyć, iż art. 1 ustawy o pracownikach samorządowych jest odesłaniem do działań służby cywilnej, a dokładniej do art. 153 ust. 1 Konstytucji RP, zgodnie z którym służba cywilna działa w celu zapewnienia zawodowego, rzetelnego, bezstronnego i politycznie neutralnego wykonywania zadań państwa. Zbieżny charakter obu

3 A. Rzetecka-Gil, Ustawa o pracownikach samorzadowych. Komentarz, Warszawa 2009, s. 9-13.

4 Dz.U. Nr 78 poz. 483 ze zm. 
artykułów podkreśla pożądane cechy u pracowników samorządowych i służby celnej5.

Z uwagi na powyższe można jasno powiedzieć, iż do podstawowych cech pracowników samorządowych zalicza się m.in. profesjonalizm, który oznacza powinność posiadania przez pracowników samorządowych odpowiednich kwalifikacji niezbędnych do wykonywania powierzonych im zadań i obowiązków. Ponadto wykonywana praca powinna mieć charakter stały, zapewniając przy tym możliwość realizacji kariery zawodowej pracownika. Wiąże się to z zawodowością pracowników, która opiera się na stabilności zawodowej oraz przejrzystych regułach naboru na konkretne stanowiska pracy. Wskazane cechy są powiązane z rzetelnością wykonywania zadań publicznych, czyli w sposób wiarygodny i odpowiadający wszystkim wymaganiom. Wszelkie czynności realizowane przez pracowników samorządowych powinny cechować się starannością, sumiennością i dbałością o przestrzeganie prawa i godność urzędu z zachowaniem uprzejmego kontaktu z obywatelami i swoimi zwierzchnikami6.

Od pracownika samorządowego wymagana jest także bezstronność, czyli wykonywanie zadań wolne od jakichkolwiek nacisków, wpływów czy uprzedzeń. Obowiązkiem pracownika jest kierowanie się dobrem publicznym przy zachowaniu obiektywizmu. Przepisy administracyjne przewidują bowiem możliwość wyłączenia pracownika od załatwiania jakiejś sprawy. Może to być spowodowane pozostawaniem $\mathrm{z}$ jedną ze stron $\mathrm{w}$ stosunku prawnym, który może mieć wpływ na podejmowane decyzje lub sprawy dotyczące małżonka, krewnych, powinowatych, itd. Inną okoliczności wyłączająca pracownika są wątpliwości co do jego bezstronności. W przypadku podjęcia decyzji uzasadnionej podejrzeniem o stronniczość czy interesowność pracownik może spodziewać się niezwłocznego rozwiązania z nim

5 A. Piskorz-Ryń, I. Ślęczkowska, Ustawa o pracownikach samorządowych. Komentarz, Wrocław 2009, s. 13-17.

6 P. Groński, Ustawa o pracownikach samorządowych. Komentarz, Warszawa 2010, s. $12-16$. 
stosunku pracy lub odwołania go ze stanowiska. Pracownik powinien być również apolityczny, czyli całkowicie neutralny politycznie. Jednakże w odróżnieniu od pracowników służby cywilnej pracownicy samorządowi mają prawo należeć do partii politycznych (możliwość ta nie dotyczy sekretarza gminy, powiatu i województwa). Przynależność do partii politycznych nie jest równoznaczna z prawem manifestowania swoich poglądów politycznych, zwłaszcza w swoim miejscu pracy ${ }^{7}$.

\section{2. „Zasady nabywania prawa do „nagród jubileuszowych" przez pracowników samorządowych w świetle obowiązujących przepisów prawa}

Pracownicy samorządowi, zgodnie z art. 36 ust. 2 ustawy o pracownikach samorządowych, poza otrzymywanym wynagrodzeniem zasadniczym mają także prawo do dodatku za wieloletnią pracę, „nagrody jubileuszowej" oraz jednorazowej odprawy w związku z przejściem na emeryturę lub rentę z tytułu niezdolności do pracy. „Nagroda jubileuszowa" jest świadczeniem związanym z pozostawaniem w zatrudnieniu przez określony w ustawie okres czasu. Przysługuje ona każdemu pracownikowi samorządowemu bez względu na podstawę nawiązania stosunku pracy (czy to jest pracownik umowny, z wyboru czy z powołania) ${ }^{8}$. Wynosi ona, w myśl art. 38 ust. 2 niniejszej ustawy, odpowiednio:

1. po 20 latach pracy $-75 \%$ wynagrodzenia miesięcznego,

2. po 25 latach pracy $-100 \%$ wynagrodzenia miesięcznego,

3. po 30 latach pracy $-150 \%$ wynagrodzenia miesięcznego,

4. po 35 latach pracy $-200 \%$ wynagrodzenia miesięcznego,

\section{Tamże.}

8 M. Rycak, Komentarz do art. 38 ustawy o pracownikach samorzqdowych, [w:] M. Rycak, A. Rycak, J. Stelina, Ustawa o pracownikach samorządowych. Komentarz, Warszawa 2013, s. 231. 
5. po 40 latach pracy - $300 \%$ wynagrodzenia miesięcznego,

6. po 45 latach pracy $-400 \%$ wynagrodzenia miesięcznego.

W doktrynie przeważają poglądy, że „nagroda jubileuszowa” jest świadczeniem o charakterze premiowym. Podlega ona ochronie prawnej tak jak wynagrodzenie, więc należy przyjąć, iż jest to świadczenie o charakterze wynagrodzeniowym. „Nagroda jubileuszowa” odpowiada w dużej mierze doktrynalnej definicji wynagrodzenia, którym jest obowiązkowe, wypłacane okresowo świadczenie ze stosunku pracy o charakterze przysparzającym, mające z reguły charakter wzajemny jako świadczenie należne pracownikowi od pracodawcy za wykonaną pracę 9 .

Należy zauważyć, iż „nagroda jubileuszowa” przysługuje na postawie przepisów szczególnych, zwłaszcza z mocy pragmatyk pracowniczych oraz układów zbiorowych pracy. Może ona ulec przedawnieniu po upływie 3 lat od daty jej wymagalności, czyli od dnia, w którym pracownik uzyskał odpowiedni staż pracy uprawniający do nabycia nagrody. Wynagrodzenie, które jest podstawą do naliczenia nagrody, oblicza się według zasad naliczania ekwiwalentu pieniężnego za urlop wypoczynkowy ${ }^{10}$.

Warunkiem nabycia prawa do „nagrody jubileuszowej” jest zatrudnienie przez dany okres uprawniający do nagrody. Okres uprawniający do nagrody obejmuje okres całego zatrudnienia, okresy poprzednio zakończonego zatrudnienia, a także inne okresy, jeśli z mocy odrębnych przepisów zaliczane są jako warunkujące prawo do nagrody ${ }^{11}$. Do okresów tych zaliczamy: przebywanie na urlopie wychowawczym, pobieranie zasiłku dla bezrobotnych, pobieranie stypendium w czasie stażu absolwenckiego, pracę w gospodarstwie rolnym ( $w$ tym prowadzenie indywidualnego gospodarstwa rolnego). Szczegółowe regulacje dotyczące nagrody jubileuszowej zawarte są w roz-

9 Tamże.

10 H. Szewczyk, Stosunki pracy $w$ samorzadzie terytorialnym, Warszawa 2012, s. 252-255.

11 P. Wojnicz, Zatrudnienie w samorzadzie - umowy, wynagrodzenie, czas pracy, Wrocław 2011, s. 75. 
porządzeniu Rady Ministrów z 18 marca 2009 r. w sprawie wynagradzania pracowników samorządowych ${ }^{12}$. Zgodnie z $\S 8$ ust. 2 tego rozporządzenia $\mathrm{w}$ sytuacji, gdy pracownik pozostaje równocześnie więcej niż w jednym stosunku pracy, do okresu, który uprawnia do „nagrody jubileuszowej” wlicza się tylko jeden okres zatrudnienia. Rozporządzenie określa także, iż pracownik ma obowiązek udokumentowania swojego prawa do nagrody, gdy w jego aktach osobowych znajdujących się w zakładzie pracy brakuje odpowiedniej dokumentacji ${ }^{13}$.

Prawo do otrzymania "nagrody jubileuszowej” nie jest jednorazowe, gdyż po kolejnym okresie zatrudnienia pracownik samorządowy uprawniony jest do kolejnej nagrody. Ustawa o pracownikach samorządowych przewiduje okres 5-letni do nabycia prawa do kolejnej „nagrody jubileuszowej”. Nagroda stanowi składnik wynagrodzenia zasadniczego, jest także świadczeniem o charakterze roszczeniowym. Pracownik nabywa prawo do nagrody w dniu upływu okresu uprawniającego do niej lub $\mathrm{w}$ dniu wejścia $\mathrm{w}$ życie przepisów wprowadzających „nagrody jubileuszowe” ( $\S 8$ ust. 1 ww. rozporządzenia). W sytuacji, gdy pracownikowi samorządowemu, którego stosunek pracy ustaje $\mathrm{w}$ związku z przejściem na emeryturę lub rentę z tytułu niezdolności do pracy, brakuje mniej niż 12 miesięcy licząc od dnia ustania stosunku pracy, nagrodę wypłaca się w dniu wygaśnięcia stosunku pracy ( $\S 8$ ust. 8 tego rozporządzenia). Jeśli przepisy wprowadzą nowe okresy zaliczane do stażu pracy, dzięki czemu pracownikowi przysługiwać będzie więcej niż jedna nagroda, wypłacana jest tylko nagroda wyższa. Natomiast jeśli w dniu wejścia w życie przepisów umożliwiających zaliczenie okresu dotąd niezaliczanego, w związku z czym pracownik ma okres zatrudnienia dłuższy niż wymagany do nagrody danego stopnia, należy ustalić, czy w ciągu 12 miesięcy od wejścia tych przepisów pracownikowi będzie przysługiwała nagroda wyższego stopnia. Jeśli taka sytuacja będzie miała miejsce, należy

\footnotetext{
Tekst jedn. Dz.U. z 2014 r., poz. 1786.

13 D. Wołoszyn-Kądziołka (red.), Wynagrodzenia pracowników samorządowych. Komentarz, przykłady, pytania i odpowiedzi, przepisy, Warszawa 2011, s. 61-63.
} 
wówczas wypłacić niższą nagrodę w pełnej kwocie, a gdyby pracownik nabył prawo do nagrody wyższej, wypłaca się różnicę pomiędzy kwotą wyższej i niższej nagrody ${ }^{14}$.

Zgodnie z wyrokiem Sądu Najwyższego z dnia 19 sierpnia 1999 r..$^{15}$ nagroda jubileuszowa jest wymagalna od momentu nabycia do niej prawa, od tego czasu należą się od niej odsetki, nawet jeśli pracownik później wykazał okoliczności stanowiące przesłankę uprawniającą do nagrody. Wypłata nagrody powinna zatem nastąpić niezwłocznie po nabyciu do niej prawa. Przy obliczeniu jej wysokości należy wziąć pod uwagę rozporządzenie Ministra Pracy i Polityki Społecznej z 8 stycznia 1997 r. w sprawie szczególnych zasad udzielania urlopu wypoczynkowego, ustalania i wypłacania wynagrodzenia za czas urlopu oraz ekwiwalentu pieniężnego za urlop ${ }^{16}$.

Zgodnie z § 6 powyższego rozporządzenia do podstawy nagrody jubileuszowej nie wlicza się: jednorazowych wypłat za określone zadania lub osiągnięcia, wynagrodzenia za czas gotowości do pracy oraz za czas niezawinionego przez pracownika przestoju, nagród jubileuszowych, wynagrodzenia za czas urlopu wypoczynkowego, a także innej usprawiedliwionej nieobecności w pracy, ekwiwalentu pieniężnego za urlop wypoczynkowy, dodatkowego wynagrodzenia radcy prawnego z tytuły zastępstwa sądowego, wynagrodzenia za czas niezdolności do pracy wskutek choroby lub odosobnienia w związku z chorobą zakaźną, kwoty wyrównania do wynagrodzenia za pracę do wysokości minimalnego wynagrodzenia za pracę, nagród z zakładowego funduszu nagród, dodatkowego wynagrodzenia rocznego, należności przysługujących z tytułu udziału w zyskach, odpraw emerytalnych lub rentowych, wynagrodzenia i odszkodowania przysługującego $\mathrm{w}$ razie rozwiązania stosunku pracy.

Składniki wynagrodzenia określone w stawce miesięcznej w stałej wysokości uwzględnia się $\mathrm{w}$ wysokości należnej pracownikowi

\footnotetext{
H. Szewczyk, Stosunki..., s. 252-253.

I PKN 189/99; OSNP z 2000 r. Nr 22, poz. 819.

Dz.U. Nr 2, poz. 14 ze zm.
} 
samorządowemu w miesiącu nabycia prawa do nagrody. Do stałych składników wynagrodzenia włącza się m.in. wynagrodzenie zasadnicze, dodatek funkcyjny, dodatek stażowy, dodatek specjalny. Natomiast zmienne składniki to np.: premie regulaminowe, wynagrodzenia za pracę $w$ porze nocnej lub $w$ godzinach nadliczbowych. Uwzględnia się je w średniej wysokości z trzech miesięcy poprzedzających miesiąc, w który pracownik nabył prawo do nagrody. Jeśli pracownik nie przepracował pełnych trzech miesięcy, to wynagrodzenie faktycznie wypłacone dzieli się przez liczbę dni pracy, za które dostał wynagrodzenie i otrzymany wynik mnoży się przez liczbę dni, jakie by przepracował w ramach normalnego czasu pracy ${ }^{17}$.

Jeżeli pracownikowi nie przysługiwało wynagrodzenie określone zmiennymi składnikami wynagrodzenia przez cały okres przyjęty do ustalenia podstawy wymiaru, poprzedzający miesiąc nabycia prawa do nagrody lub przez okres krótszy, ale obejmujący pełny miesiąc kalendarzowy lub pełne miesiące kalendarzowe, to w podstawie wymiaru należy uwzględnić najbliższe miesiące, za które pracownikowi takie wynagrodzenie przysługiwało. Zgodnie z $§ 11$ ust. 2 ww. rozporządzenia, jeśli pracownik przed nabyciem prawa do nagrody jubileuszowej otrzymał zmienne składniki wynagrodzenia za okres krótszy niż trzy miesiące, to za podstawę wymiaru uważa się wynagrodzenie wypłacone pracownikowi za okres faktycznie przepracowany. Natomiast zamienne składniki wynagrodzenia za okresy dłuższe niż miesiąc zalicza się w średniej wysokości wypłaconej w okresie 12 miesięcy bezpośrednio poprzedzających miesiąc nabycia prawa do nagrody jubileuszowej (§ 17 ust. 1 rozporządzenia) ${ }^{18}$.

\section{Oskładkowanie „nagród jubileuszowych”}

W przypadku nabycia przez pracownika samorządowego prawa do „nagrody jubileuszowej” - płatnik składek, tj. odpowiednia jednostka,

17 D. Wołoszyn-Kądziołka (red.) Wynagrodzenia..., s. 68-73.

18 Tamże. 
która zatrudnia pracownika, jest zobowiązana na podstawie obowiązujących przepisów do odprowadzenia składek na ubezpieczenie społeczne i zdrowotne od prawidłowo wypłaconego świadczenia. Aby określić, jakie kwoty składek na ubezpieczenie społeczne płatnik składek jest zobowiązany ponieść, konieczne jest ustalenie podstawy wymiaru składek, którą jest kwota pieniężna dająca po przemnożeniu przez obowiązującą stopę procentową kwotę należnych składek ${ }^{19}$.

Podstawą wymiaru składek na ubezpieczenie emerytalne i rentowe pracowników, w tym pracowników samorządowych, zgodnie z art. 18 ust. 1 ustawy z dnia 13 października 1998 r. o systemie ubezpieczeń społecznych ${ }^{20}$ jest przychód, o którym mowa w art. 4 pkt 9 tej ustawy. Odwołując się do ww. przepisu, ustawodawca za przychód uznaje przychody w rozumieniu przepisów o podatku dochodowym od osób fizycznych z tytułu: zatrudnienia w ramach stosunku pracy, pracy nakładczej, służby, wykonywania mandatu posła lub senatora, wykonywania pracy w czasie odbywania kary pozbawienia wolności lub tymczasowego aresztowania, pobierania zasiłku dla bezrobotnych, świadczenia integracyjnego i stypendium wypłacanych bezrobotnym oraz stypendium sportowego, a także z tytułu prowadzenia pozarolniczej działalności oraz umowy agencyjnej lub umowy zlecenia, jak również z tytułu współpracy przy tej działalności lub współpracy przy wykonywaniu umowy oraz przychody z działalności wykonywanej osobiście przez osoby należące do składu rad nadzorczych, niezależnie od sposobu ich powoływania.

Określenie, co stanowi, a co nie stanowi podstawy wymiaru składek, wymaga więc w pierwszym rzędzie sięgnięcia do przepisów ustawy z dnia 26 lipca 1991 r. o podatku dochodowym od osób fizycznych ${ }^{21}$. W myśl art. 12 ust. 1 tej ustawy za przychody ze stosunku służbowego, stosunku pracy, pracy nakładczej oraz spółdzielczego

19 P. Kostrzewa, Rozdział I. System ubezpieczeń Społecznych, [w:] J. Kuźniar (red.), Ubezpieczenia społeczne 2015, Warszawa 2015, s. 27-28.

20 Tekst jedn. Dz.U. z 2015 r., poz. 121 ze zm.

21 Tekst jedn. Dz.U. z 2012 r., poz. 361 ze zm. 
stosunku pracy uważa się wszelkiego rodzaju wypłaty pieniężne oraz wartość pieniężną świadczeń w naturze bądź ich ekwiwalenty, bez względu na źródło finansowania tych wypłat i świadczeń, a w szczególności: wynagrodzenia zasadnicze, wynagrodzenia za godziny nadliczbowe, różnego rodzaju dodatki, nagrody, ekwiwalenty za niewykorzystany urlop i wszelkie inne kwoty niezależnie od tego, czy ich wysokość została z góry ustalona, a ponadto świadczenia pieniężne ponoszone za pracownika, jak również wartość innych nieodpłatnych świadczeń lub świadczeń częściowo odpłatnych.

Ustawodawca przewidział jednak możliwość modyfikacji podstawy wymiaru składek dla pracowników w oparciu o rozporządzenie Ministra Pracy i Polityki Socjalnej z dnia 18 grudnia 1998 r. w sprawie szczegółowych zasad ustalania podstawy wymiaru składek na ubezpieczenie emerytalne i rentowe ${ }^{22}$, które enumeratywnie wylicza rodzaje przychodów niestanowiących podstawy wymiaru składek na ubezpieczenie społeczne. I tak w myśl $\S 2$ ust. 1 pkt 1 tego rozporządzenia z podstawy wymiaru składek na ubezpieczenie emerytalne i rentowe wyłączone zostały przychody stanowiące wartość finansowanych przez pracodawcę „nagród jubileuszowych (gratyfikacji), które według zasad określających warunki ich przyznawania przysługują pracownikowi nie częściej niż co 5 lat". Dla wyłączenia z podstawy wymiaru składek nie ma większego znaczenia, czy nagroda jubileuszowa wypłacana jest na podstawie przepisów powszechnie obowiązujących czy wewnętrznych obowiązujących u danego pracodawcy (np. zbiorowe układy pracy) ${ }^{23}$.

Jak wskazuje Ł. Prasołek w komentarzu do ustawy o systemie ubezpieczeń społecznych pod redakcją B. Gudowskiej oraz J. Strusińskiej-Żukowskiej w zakresie wyłączenia nagród jubileuszowych z podstawy wymiaru składek na ubezpieczenie społeczne nadal aktu-

Tekst jedn. Dz.U. z 2015 r., poz. 2236 ze zm.

23 Ł. Prasołek, Komentarz do artykułu 18 ustawy o systemie ubezpieczeń społecznych, [w:] B. Gudowska, J. Strusińska-Żukowska (red.), Ustawa o systemie ubezpieczeń społecznych: komentarz, Warszawa 2011, s. 350. 
alny jest pogląd Sądu Najwyższego wyrażony w wyroku z dnia 29 października 2002 r. ${ }^{24}$, zgodnie z którym przyznane pracownikowi przez pracodawcę świadczenie może być uznane za nagrodę jubileuszową, jeżeli warunkiem jego przyznania jest przepracowanie określonego w latach okresu czasu. Sąd Najwyższy w uzasadnieniu tego wyroku wyraźnie podkreślił, że wyłączeniu z podstawy wymiaru składek nie podlegają inne nagrody, a dla osiągnięcia skutku wyłączenia z podstawy wymiaru składek nie wystarczy nazwanie przez pracodawcę danego składnika wynagrodzenia nagrodą jubileuszową, gdyż określone $\mathrm{w}$ przepisach wewnętrznych zasady jego przyznawania muszą odpowiadać pojęciu nagrody jubileuszowej25.

Zgodnie z interpretacją przepisów dokonaną przez Ministerstwo Pracy i Polityki Społecznej wypracowano stanowisko, w myśl którego wolna od składek na ubezpieczenie społeczne jest również nagroda jubileuszowa, gdy:

1. pracownik nabywa ją przed upływem 5 lat od nabycia prawa do kolejnej nagrody, ale na skutek przedłożenia w tym okresie dokumentów poświadczających zatrudnienie w okresach, które wcześniej nie były brane pod uwagę przy ustalaniu prawa do nagrody,

2. nagroda jest wypłacana $w$ dniu rozwiązania stosunku pracy pracownikowi, któremu do nabycia prawa do nagrody z tytułu upływu kolejnych 5 lat brakuje mniej niż 12 miesięcy, a rozwiązanie stosunku pracy następuje w związku z przejściem na emeryturę lub rentę,

3. jest wypłacana członkom drużyn ratowniczych przemysłu wydobywczego (z wyjątkiem specjalistów) bez względu na częstotliwość wypłaty nagrody, gdyż przepisy dotyczące tego zawodu dopuszczają częstsze okresy wypłat nagród jubileuszowych ${ }^{26}$.

\footnotetext{
4 II UKN 461/01, Baza Orzeczeń Sądu Najwyższego, http://www.sn.pl/orzecznictwo.

25 Ł. Prasołek, Komentarz do artykułu..., s. 350-351.

26 Tamże.
} 
Jeśli chodzi o regulowanie składek na ubezpieczenie zdrowotne, należy odnieść się do zasady określonej przez ustawodawcę w art. 81 ust. 1 ustawy z dnia 27 sierpnia 2004 r. o świadczeniach opieki zdrowotnej finansowanych ze środków publicznych ${ }^{27}$, zgodnie z którym do ustalenia podstawy wymiaru składek na ubezpieczenie zdrowotne pracowników stosuje się odpowiednio przepisy określające podstawę wymiaru składek na ubezpieczenie społeczne. W związku z tym składce na ubezpieczenie zdrowotne nie podlegają te nagrody jubileuszowe, od których nie ma obowiązku odprowadzania składek na ubezpieczenie społeczne.

\section{Zasady nabywania prawa do „nagrody jubileuszowej" i kwestia jej oskładkowania w świetle orzecznictwa sądowego}

Kwestia zasad nabywania prawa do „nagród jubileuszowych” przez pracowników samorządowych oraz kwestia oskładkowania tychże świadczeń bardzo rzadko pojawia się w orzecznictwie sądów powszechnych. Zagadnienia te są niemalże niszowymi sprawami na wokandach sądów, co może świadczyć o tym, że pracodawcy, którzy wypłacają te nagrody w związku z osiągnięciem określonego stażu pracy swoim pracownikom, nie mają problemów z właściwą interpretacją i wykładnią przepisów dotyczących tychże nagród.

Po długotrwałym przeszukiwaniu archiwów sądów administracyjnych, powszechnych, Sądu Najwyższego oraz baz prawniczych Legalis oraz Lex udało się dotrzeć zaledwie do kilku orzeczeń poruszających problematykę zasad nabywania oraz zasad oskładkowania „nagród jubileuszowych”, tj. wyroku Wojewódzkiego Sądu Administracyjnego w Gliwicach z dnia 16 lipca 2009 r.28, wyroku Naczelnego

\footnotetext{
Tekst jedn. Dz.U. z 2015 r., poz. 581 ze zm.

28 IV SA/Gl 271/09, Centralna Baza Orzeczeń Sądów Administracyjnych (CBOSA), http://orzeczenia.nsa.gov.pl.
} 
Sądu Administracyjnego z dnia 9 listopada 2007 r. ${ }^{29}$, wyroku Sądu Najwyższego z dnia 12 lutego 2010 r. ${ }^{30}$ oraz wyroku Sądu Apelacyjnego w Szczecinie z dnia 30 października 2014 r. ${ }^{31}$

W wyroku WSA w Gliwicach z dnia 16 lipca 2009 r. sąd zajął się kwestią ważności uchwały Rady Powiatu, która przyznała i wypłaciła przewodniczącemu zarządu powiatu „nagrodę jubileuszową” w wysokości $450 \%$ miesięcznego wynagrodzenia w związku z jubileuszem 50 lat pracy. Sąd uznał uchwałę za wadliwą, gdyż została ona podjęta z naruszeniem upoważnienia ustawowego. „Nagroda jubileuszowa”, zdaniem WSA w Gliwicach, może być przyznawana i wypłacana wyłącznie w granicach określonych przez przepisy ustawy o pracownikach samorządowych, które są bezwzględnie obowiązujące. Jak dalej wskazuje Sąd, „przesłanki decydujące o jej przyznaniu są uregulowane wyczerpująco, a podmiotowi decydującemu nie służy władza dyskrecjonalna, bowiem jest on zobowiązany przepisem rangi ustawowej. W konsekwencji wszelkie odstępstwa od określonych we wskazanym przepisie zasad, w tym zmiana okresu lat pracy, po jakich przysługuje nagroda jubileuszowa, są niedopuszczalne i nie mogą zostać zaakceptowane".

WSA w Gliwicach odniósł się także do nieprawidłowego stanowiska organu $\mathrm{w}$ zakresie stosowania przepisów Kodeksu Pracy, stwierdzając, że „w rozpoznawanej sprawie nie znajdują zastosowania przepisy Kodeksu pracy, które w rzeczywistości przewidują możliwość kształtowania treści stosunku pracy w oparciu o bardziej korzystne warunki, niż te przewidziane w samym Kodeksie, jednakże ustawa o pracownikach samorządowych w jej art. 31 ust. 1 ustanowiła generalną zasadę, że wyłącznie w kwestiach w niej nieuregulowanych stosuje się odpowiednio przepisy Kodeksu pracy. Mając na uwadze powyższe rozważania nie ulega wątpliwości, iż w niniejszej sprawie przepisy prawa pracy nie obowiązują, gdyż zasady przyznania

\footnotetext{
II OSK 1357/07, CBOSA.

II PK 214/09, Baza Orzeczeń Sądu Najwyższego.

III AUa 136/14, Legalis nr 1229702.
} 
pracownikom samorządowym nagrody jubileuszowej zostały wyczerpująco uregulowane w ustawie o pracownikach samorządowych".

Podsumowując, w analizowanej sprawie Rada Powiatu nie posiadała uprawnień, aby ustalać zasady przyznawania i wypłacania nagrody jubileuszowej za 50 lat pracy, gdyż ustawa o pracownikach samorządowych nie przewiduje możliwości wypłacenia takiej nagrody. Regulacje tej ustawy oraz rozporządzeń wykonawczych w zakresie zasad ustalania i wypłacania wynagrodzenia pracownikom samorządowym są regulacjami wyczerpującymi i klarownymi nie zezwalającymi na dokonanie jakichkolwiek innych rozszerzeń.

Sąd Najwyższy w wyroku z dnia 12 lutego 2010 r. stwierdził, że „nagroda jubileuszowa ma charakter dodatkowego wynagrodzenia w związku z wieloletnim świadczeniem pracy. Pracownik nabywa do niej prawo $\mathrm{z}$ chwilą przepracowania odpowiedniego okresu, przy spełnieniu innych niezbędnych przewidzianych prawem przesłanek. Decydujące znaczenie do nabycia prawa do nagrody jubileuszowej ma pozostawanie pracownika w stosunku pracy. Celem zaś nagrody jubileuszowej jest docenienie finansowe wieloletniej aktywności zawodowej pracownika. Pracodawca nie ma natomiast obowiązku przedłużania stosunku pracy w celu umożliwienia pracownikowi nabycia prawa do nagrody jubileuszowej".

NSA w wyroku z dnia 9 listopada 2007 r. zajął się kwestią przyznanej „nagrody jubileuszowej” przez radę gminy wójtowi oraz problematyką tego, czy „nagroda jubileuszowa” wchodzi w zakres użytego w ustawie o pracownikach samorządowych pojęcia „ustalania wynagrodzenia", czy nie. Jak wskazał skarżący, nagroda jubileuszowa i dodatkowe wynagrodzenie roczne pracownika samorządowego wchodzą w zakres pojęcia „wynagrodzenie”, a nawet „wynagrodzenia za pracę". Istota sporu sprowadzała się do tego, czy przyznanie tych świadczeń jest ustaleniem wynagrodzenia, o którym mowa w przepisach ustawy o pracownikach samorządowych, czy nie. Określenie „ustalać” oznacza „szczegółowo coś określić/określać, rozstrzygnąć (rozstrzygać), zdecydować (decydować) o ostatecznej formie, postaci, 
przebiegu czegoś, wyznaczyć (wyznaczać)". Zdaniem NSA, aby uzyskać nagrodę jubileuszową oraz dodatkowe wynagrodzenie roczne, wójt gminy musi spełnić określone przepisami przesłanki, a ich zaistnienie musi zbadać - ustalić - właściwy organ - rada gminy, który następnie decyduje o ich przyznaniu w wysokości ustalonej w oparciu o obowiązujące przepisy. Zatem $\mathrm{w}$ użytym $\mathrm{w}$ przepisach ustawy o pracownikach samorządowych zwrocie „prawo do ustalania wynagrodzenia" mieści nie tylko wynagrodzenie sensu stricte, ale także dodatkowe wynagrodzenie roczne i nagroda jubileuszowa.

Sąd Apelacyjny w Szczecinie w wyroku z dnia 30 października 2014 r. zajął się kwestią nazewnictwa świadczeń wypłacanych pracownikowi nie z powodu osiągnięcia określonego stażu pracy, lecz z powodu przejścia na emeryturę po rozwiązaniu stosunku pracy z przyczyn leżących po stronie pracodawcy. Sąd w wyroku starał się udowodnić tezę, iż „podstawową przesłanką przyznania nagrody jubileuszowej jest osiągnięcie określonego stażu pracy. Jeżeli powodem przyznania świadczenia nazwanego nagrodą jubileuszową nie było osiągnięcie określonego stażu pracy, ale przejście na emeryturę po rozwiązania stosunku pracy z przyczyn leżących po stronie pracodawcy, to takie świadczenie należy zakwalifikować jako odprawę pieniężną, która nie stanowi podstawy wymiaru składek na ubezpieczenia społeczne i ubezpieczenie zdrowotne".

W uzasadnieniu sąd wskazał, iż zwolnienia z podstawy wymiaru składek zawarte w przepisie $\S 2$ ust. 1 pkt 1 rozporządzenia Ministra Pracy i Polityki Społecznej z dnia 18 grudnia 1998 r. mają charakter przywileju, stanowiąc odstępstwo od zasady powszechności oskładkowania przychodów z tytułu stosunku pracy, a w konsekwencji powinny być interpretowane bez dokonywania wykładni rozszerzającej. Zgodnie z utrwalonym orzecznictwem Sądu Najwyższego ${ }^{32}$ i jednolitym stanowiskiem doktryny prawa ubezpieczeń społecznych, przepisy prawa ubezpieczeń społecznych powinny być wykładane ściśle, co

32 Wyrok SN z dnia 9 listopada 1999 r., II UKN 187/99; wyrok SN z dnia 16 sierpnia 2005 r., I UK 378/04, Baza Orzeczeń Sądu Najwyższego. 
oznacza w zasadzie prymat dyrektyw wykładni językowej w odniesieniu do pozostałych metod wykładni, w tym wykładni systemowej i wykładni historycznej lub celowościowej ${ }^{33}$.

Inaczej mówiąc, z literalnego brzmienia przepisu § 2 ust. 1 pkt 1 wskazanego rozporządzenia wynika, że z podstawy wymiaru składek na ubezpieczenia społeczne wyłączone są jedynie takie nagrody jubileuszowe, „które według zasad określających warunki ich przyznawania przysługują pracownikowi nie częściej niż co 5 lat”. Z powyższego wywieść należy, że decydujące znaczenie w kontekście zwolnienia tego typu świadczeń pieniężnych z obowiązku opłacania składek na ubezpieczenia społeczne ustawodawca przypisał periodycznemu (nie częstszemu niż co 5 lat) nabywaniu przez pracownika prawa do ich uzyskania na podstawie wewnętrznych przepisów obowiązujących u pracodawcy.

W uzasadnieniu sąd wskazywał, że w doktrynie „nagroda jubileuszowa" uznawana jest za świadczenie przyznawane pracownikowi w związku z upływem określonego czasu pracy, czyli stażu. Nie jest to świadczenie powszechne. Nie wynika z żadnego przepisu prawa obejmującego wszystkich pracowników. „Jubileuszówka” jest domeną tzw. pragmatyk zawodowych oraz wewnętrznych przepisów czy układów zbiorowych. Wskazanie uniwersalnych zasad jej naliczania i wypłaty jest w zasadzie niemożliwe. Istota nagrody jubileuszowej sprowadza się do przyznania pracownikowi pewnego świadczenia w związku z faktem nabycia odpowiedniego stażu pracy. Nie zawsze jest to ogólny staż pracy, może być to zakładowy staż pracy. Nagroda jubileuszowa, mimo że nie jest świadczeniem powszechnym, stanowi jednak element systemu wynagradzania pracowników, stąd przepisy prawa pozwalają obciążyć to świadczenie składkami na ubezpieczenia społeczne.

Kwestią sporną tego postępowania przed sądem było ustalenie, czy świadczenia wypłacone skarżącym powinny być wliczone do podstawy wymiaru składek na ubezpieczenia społeczne i ubezpieczenie

33 Wyrok SN z dnia 25 czerwca 2008 r., II UK 315/07, Baza Orzeczeń Sądu Najwyższego. 
zdrowotne, a ponadto jak powinno się dane świadczenie prawidłowo zakwalifikować. Powodem przyznania świadczenia nazwanego nagrodą jubileuszową nie było osiągnięcie określonego stażu pracy, ale przejście na emeryturę po rozwiązaniu stosunku pracy z przyczyn leżących po stronie pracodawcy, więc zdaniem sądu takiego świadczenia nie należało zakwalifikować jako „nagrody jubileuszowej” lecz jako odprawę pieniężną.

Jak wskazywał Sąd w uzasadnieniu zgodnie z § 2 ust. 1 pkt 2 powoływanego rozporządzenia, podstawy wymiaru składek nie stanowią przychody - odprawy pieniężne przysługujące w związku z przejściem na emeryturę lub rentę. Natomiast zgodnie z $§ 2$ ust. 1 pkt 3 podstawy wymiaru składek nie stanowią przychody - odprawy, odszkodowania i rekompensaty wypłacane pracownikom z tytułu wygaśnięcia lub rozwiązania stosunku pracy, w tym z tytułu rozwiązania stosunku pracy z przyczyn leżących po stronie pracodawcy. W ocenie sądu głównymi przesłankami wypłaty zainteresowanym świadczeń pieniężnych były: przejście na emeryturę oraz rozwiązanie stosunku pracy. Zatem pomimo że świadczenia te zostały potraktowane jak „proporcjonalna nagroda jubileuszowa”, należało mieć na uwadze rzeczywisty charakter wypłaconych świadczeń, a nie samą ich nazwę.

W ocenie Sądu Apelacyjnego to nie nazwa świadczenia użyta w przepisach płacowych, ale warunki jego nabycia i ogół czynności określający zasady jego przyznawania decydują o prawidłowej kwalifikacji świadczenia. W tym kontekście należy podkreślić, że warunkiem wypłaty spornych świadczeń był fakt przejścia przez zainteresowanego na emeryturę. Jedynie wysokość świadczenia zależała od tego, jaki okres upłynął od ostatnio wypłaconych nagród jubileuszowych. Sąd Apelacyjny akcentuje, że podstawową przesłanką przyznania nagrody jubileuszowej jest jednak osiągnięcie określonego stażu pracy. 


\section{Podsumowanie}

Pracownicy samorządowi, których uprawnienia uregulowane są w akcie prawnym o randze ustawy, zwanym pragmatyką zawodową, obok otrzymywanego co miesiąc wynagrodzenia zasadniczego mają prawo do: dodatku za wieloletnią pracę, odprawy emerytalnej i rentowej oraz „nagrody jubileuszowej”. „Nagroda jubileuszowa” w doktrynie uznawana jest za świadczenie przyznawane pracownikowi w związku z upływem określonego w ustawie czasu pracy, czyli stażu. Istota nagrody jubileuszowej sprowadza się do przyznania pracownikowi pewnego świadczenia w związku z faktem nabycia odpowiedniego stażu pracy, np. po przepracowaniu 35 lat pracy pracownikowi samorządowego będzie przysługiwać „nagroda jubileuszowa” w wysokości 200\% wynagrodzenia miesięcznego.

Prawo do otrzymania "nagrody jubileuszowej” nie jest jednorazowe, gdyż po kolejnym okresie zatrudnienia pracownik samorządowy uprawniony jest do kolejnej nagrody. Ustawa o pracownikach samorządowych przewiduje okres 5-letni do nabycia prawa do kolejnej „nagrody jubileuszowej”. Nagroda stanowi składnik wynagrodzenia zasadniczego, jest świadczeniem o charakterze roszczeniowym. Pracownik nabywa prawo do nagrody w dniu upływu okresu uprawniającego do niej lub w dniu wejścia w życie przepisów wprowadzających "nagrody jubileuszowe”.

„Nagroda jubileuszowa” mimo że nie jest świadczeniem powszechnym stanowi element systemu wynagradzania pracowników, stąd przepisy prawa pozwalają obciążyć to świadczenie składkami na ubezpieczenia społeczne i zdrowotne, pod warunkiem iż świadczenie to będzie wypłacane częściej niż co 5 lat. Zgodnie z $§ 2$ ust. 1 pkt 1 rozporządzenia Ministra Pracy i Polityki Socjalnej z dnia 18 grudnia 1998 r. w sprawie szczegółowych zasad ustalania podstawy wymiaru składek na ubezpieczenie emerytalne i rentowe z podstawy wymiaru składek na ubezpieczenie emerytalne i rentowe wyłączone zostały przychody stanowiące wartość finansowanych przez pracodawcę „nagród jubileuszowych (gratyfikacji), które według zasad określają- 
cych warunki ich przyznawania przysługują pracownikowi nie częściej niż co 5 lat". Zgodnie z tym od wypłacanych co 5 lat pracownikom samorządowym świadczeń zwanych „nagrodami jubileuszowymi" płatnicy składek nie będę musieli odprowadzać składek na ubezpieczenie społeczne i zdrowotne.

W związku z wydłużeniem wieku emerytalnego w Polsce wprowadzonego ustawą z dnia 11 maja 2012 r. ${ }^{34}$ ustawodawca powinien dokonać zmiany $\mathrm{w}$ przepisach ustawy o pracownikach samorządowych, poszerzając katalog o nagrody jubileuszowe za 50 lat pracy (np. w wysokości np. $500 \%$ wynagrodzenia miesięcznego) oraz za 55 lat pracy (np. w wysokości 600\% wynagrodzenia miesięcznego). Wydłużenie wieku emerytalnego wiąże się $\mathrm{z}$ wydłużeniem okresu zatrudnienia pracowników, co oznacza, że coraz większa liczba pracowników będzie nabywała prawo do „nagród jubileuszowych” za kolejne lata pracy i świętowała z tym związany jubileusz.

Dobrze by było, aby wprowadzony przepis miał zastosowanie także do pracowników, którzy nabyli prawo do takiej nagrody wcześniej, ale z uwagi na brak zapisów ustawowych z takiego uprawnienia nie skorzystali. Wypełniłoby to gwarancję zawartą w art. 32 Konstytucji RP, zgodnie z którą „Wszyscy są wobec prawa równi. Wszyscy mają prawo do równego traktowania przez władze publiczne. Nikt nie może być dyskryminowany w życiu politycznym, społecznym lub gospodarczym z jakiejkolwiek przyczyny". Taka regulacja oczywiście wiązałaby się z zapewnieniem odpowiednich środków finansowych na wypłatę „nagród jubileuszowych”, co okazałoby się dla wielu pracodawców pewnie zbyt kosztowne.

Podsumowując, „nagroda jubileuszowa” jest specyficznym uprawnieniem dla pracowników samorządowych uregulowanym w akcie prawnym będącym specyficznym rodzajem pragmatyki zawodowej. Kształt i regulacje prawne tej nagrody nie budzą większych

\footnotetext{
34 Ustawa z dnia 11 maja 2012 r. o zmianie ustawy o emeryturach i rentach z Funduszu Ubezpieczeń Społecznych oraz niektórych innych ustaw (Dz.U. 2012 r., poz. 637).
} 
wątpliwości interpretacyjnych, z tym że ustawodawca powinien wprowadzić regulacje dodatkowe poszerzające katalog nabywania tej nagrody po przepracowaniu odpowiednio 50 i 55 lat.

\section{Literatura:}

1. Groński P., Ustawa o pracownikach samorzq̨dowych. Komentarz, Łącki i Skibniewski Oficyna Wydawnicza, Warszawa 2010.

2. Kostrzewa P., Rozdział I. System ubezpieczeń Społecznych, [w:] J. Kuźniar (red.), Ubezpieczenia społeczne 2015, Wydawnictwo Wolters Kluwer, Warszawa 2015.

3. Piskorz-Ryń A., Ślęczkowska I., Ustawa o pracownikach samorzq̨dowych. Komentarz, Wydawnictwo Presscom, Wrocław 2009.

4. Prasołek Ł., Komentarz do artykułu 18 ustawy o systemie ubezpieczeń społecznych, [w:] B. Gudowska, J. Strusińska-Żukowska (red.), Ustawa o systemie ubezpieczeń społecznych: komentarz, Wydawnictwo C.H. Beck, Warszawa 2011.

5. Rzetecka-Gil A., Ustawa o pracownikach samorzqdowych. Komentarz, Wydawnictwo LexisNexis, Warszawa 2009.

6. Rycak M., Komentarz do art. 38 ustawy o pracownikach samorzqdowych,[w:] M. Rycak, A. Rycak, J. Stelina, Ustawa o pracownikach samorządowych. Komentarz, Wydawnictwo Wolters Kluwer, Warszawa 2013.

7. Szewczyk H., Stosunki pracy w samorzadzie terytorialnym, Wydawnictwo Wolters Kluwer, Warszawa 2012.

8. Wojnicz P., Zatrudnienie w samorzqdzie - umowy, wynagrodzenie, czas pracy, Wydawnictwo Presscom, Wrocław 2011.

9. Wołoszyn-Kądziołka D. (red.), Wynagrodzenia pracowników samorzadowych: komentarz, przykłady, pytania i odpowiedzi, przepisy, Wydawnictwo C.H. Beck, Warszawa 2011. 